\title{
LITERASI DAN PEMBUATAN BLOG PADA GURU SDN CIPAYUNG 04 PAGI
}

\author{
Ila Nafilah'), Reni Rokhayati ${ }^{2)}$, Yulia Agustin ${ }^{3)}$ \\ Program Studi Pendidikan Bahasa dan Sastra Indonesia, \\ Fakultas Bahasa dan Seni Universitas Indraprasta PGRI,
}

\begin{abstract}
Abstrak
Permendikbud 23 Tahun 2015 tentang gerakan "Penumbuhan Budi Pekerti (PBP)", berisi salah satu hal yang mengatur tentang kegiatan selama 15 (lima belas) menit diwajibkan membaca buku nonpelajaran sebelum jam pelajaran pertama dimulai yang dianggap mampu menumbuhkan dan meningkatkan keterampilan membaca. Selain literasi, pemanfaatan internet terutama media blog, menjadi sangat penting bagi para guru dalam upaya meningkatkan kreativitas menulis. Tujuan dari dilaksanakannya kegiatan tersebut adalah 1) memberikan sosialisasi kepada para pendidik di SDN Cipayung 04 Pagi Jakarta Timur mengenai pemahaman berkenaan dengan konsep-konsep, jenis-jenis, dan bentuk-bentuk literasi sehingga akan sangat membantu para guru dalam kegiatan Proses Belajar Mengajar (PBM) serta meningkatkan prestasi akademik peserta didik; 2) memberikan pemahaman dan pelatihan berkenaan tentang proses penggunaan email, memiliki, membuat, menggunakan atau memanfaatkan blog pribadi sebagai media pembelajaran. Metode yang digunakan adalah metode ceramah, diskusi, tanya-jawab, dan pemodelan. Hasil yang dicapai adalah sebagai berikut : 1) Para pendidik di SD tersebut telah mendapatkan pengetahuan dan pemahaman berkenaan dengan konsep-konsep, jenis-jenis, dan bentuk-bentuk literasi sehingga sangat membantu para guru dalam Kegiatan Belajar Mengajar (KBM) dan meningkatkan prestasi akademik peserta didik. 2) Para guru telah mendapatkan pemahaman berkenaan tentang proses penggunaan email, memiliki, membuat, menggunakan atau memanfaatkan blog pribadi sebagai media pembelajaran.
\end{abstract}

Kata kunci : Literasi; blog

\begin{abstract}
The Minister of Education and Culture Regulation (Permendikbuud) Number 23 of 2015 concerning Cultivation of Character, contains one of the things that regulates the activities of 15 minutes of reading non-learning books before the learning period begins which are considered capable of growing and improving reading skills. In addition to literacy, the use of the internet, especially blog media, is very important for teachers in an effort to improve writing creativity. The purpose of the activity was 1) to provide socialization to teachers at Cipayung 04 Pagi Public Elementary School East Jakarta regarding understanding regarding concepts, types, and forms of literacy so that it would greatly help teachers in the activities of the teaching and learning process and improve student academic achievement; 2) provide understanding and training regarding the process of using email, owning, creating, using or utilizing personal blogs as learning media. The method used is the method of lecture, discussion, question and answer, and modeling. The results achieved are as follows: 1) Teachers in the Elementary School have gained knowledge and understanding regarding concepts, types, and forms of literacy so that it is very helpful for teachers in the activities of teaching and learning processes and improving academic achievement learners. 2) Teachers have gained an understanding regarding the process of using email, owning, creating, using or utilizing personal blogs as learning media.
\end{abstract}

Keywords: Literacy, and blogs

Correspondence author: Ila Nafilah, nafilah.salsabila@gmail.com, Jakarta, Indonesia 


\section{PENDAHULUAN}

Undang-Undang Republik Indonesia (UU RI) No 20 Tahun 2003 tentang sistem pendidikan nasional (SISDIKNAS) pasal 1 ayat 1 menyatakan pendidikan adalah tentang usaha sadar dan terencana untuk mewujudkan suasana belajar dan proses pembelajaran agar peserta didik secara aktif mengembangkan potensi dirinya untuk memiliki kekuatan spiritual keagamaan, pengendalian diri, kepribadian, kecerdasan, akhlak mulia, serta keterampilan yang dibutuhkan dirinya, masyarakat, bangsa dan negara (Permendiknas, 2009:3). Koesoema (2007:8) berpendapat bahwa pendidikan sebagai proses internalisasi (penghayatan) budaya ke dalam diri individu dan masyarakat menjadi beradab. Pendidikan akan tercapai jika masyarakat sadar akan pentingnya pendidikan tersebut sehingga mereka akan menuangkan segala macam informasi, ide-ide, dan pengetahuan yang dimiliknya itu. Informasi, ide-ide, dan pengetahuannya tersebut dituang dalam bentuk aksara.

Pendidikan merupakan modal dasar untuk menyiapkan insan yang berkualitas. Pada dasarnya arti pendidikan dalam konteks/pengertian pembangunan nasional memunyai fungsi: (1) pemersatu bangsa; (2) penyamaan kesempatan; (3) pengembangan potensi (kekuatan) diri (Tim Pengembang Pusat Kurikulum, 2007:11).

Visi pendidikan nasional adalah mewujudkan sistem pendidikan sebagai pranata sosial yang kuat dan berwibawa untuk memberdayakan semua warga negara Indonesia agar berkembang menjadi manusia yang berkualitas sehingga mampu dan proaktif menjawab tantangan zaman yang selalu berubah (Tim Pengembang Pusat Kurikulum, 2007:11).

Misi pendidikan nasional adalah : (1) mengupayakan perluasan dan pemerataan kesempatan memperoleh pendidikan yang bermutu bagi seluruh rakyat Indonesia; (2) meningkatkan mutu pendidikan yang memiliki daya saing di tingkat nasional, regional, dan internasional; (3) meningkatkan relevansi pendidikan dengan kebutuhan masyarakat dan tantangan global; (4) membantu dan menfasilitasi pengembangan potensi anak bangsa secara utuh sejak usia dini sampai akhir hayat dalam rangka mewujudkan masyarakat belajar; (5) meningkatkan kesiapan masukan dan kualitas kepribadian yang bermoral; (6) meningkatkan keprofesionalan dan akuntabilitas lembaga pendidikan sebagai pusat pembudayaan ilmu pengetahuan, keterampilan, pengalaman, sikap, dan nilai berdasarkan standar yang bersifat nasional dan global; dan (7) mendorong peran serta masyarakat prinsip otonomi dalam konteks Negara Kesatuan Republik Indonesia (Tim Pengembang Pusat Kurikulum, 2007:11).

Ihsan (2005:11) membagi fungsi pendidikan menjadi dua arti, yaitu arti mikro dan arti makro. Fungsi pendidikan dalam arti mikro (sempit) ialah membantu (secara sadar) perkembangan jasmani dan rohani peserta didik, sedangkan fungsi pendidikan secara makro (luas) ialah sebagai alat: a) pengembangan pribadi; b) pengembangan warga negara; c) pengembangan kebudayaan; dan d) pengembangan bangsa.

Literasi dalam artian sederhana memunyai makna kemampuan seseorang untuk bisa baca dan tulis atau yang lebih dikenal dengan melek aksara. Akan tetapi, pada dasarnya literasi memunyai makna yang luas sebab literasi memunyai empat tingkatan penting, sebagaimana yang dikemukakan oleh Wells dalam Heryati, dkk (2010: 46) yang membagi empat tingkatan literasi, antara lain: Performatif (performative), fungsional (functional), Informasi (informational), dan epistemik (epistemic). Literasi tingkatan pertama atau performative adalah sekadar kemampuan untuk membaca dan menulis. Tingkatan kedua atau functional adalah menunjukkan kemampuan untuk menggunakan suatu bahasa 
tertentu demi keperluan hidup atau skill for survival (seperti membaca manual, mengisi formulir, dsb). Tingkatan/ tahap ketiga atau informational adalah memperlihatkan kemampuan untuk mengakses berbagai pengetahuan. Literasi tingkatan keempat atau epistemic menunjukkan kemampuan mentransformasikan/mentrasfer pengetahuan yang dimiliki.

Selain masalah literasi yang telah diungkapkan di atas, masalah yang jauh lebih penting dalam kehidupan manusia di era digitalisasi adalah perkembangan sains dan teknologi yang semakin bertambah pesat. Hal ini disebabkan karena manusia memang selalu dihadapkan pada ujian alam, situasi serta keadaan yang memicu daya kreativitasnya. Pesatnya kemajuan sains dan teknologi tersebut telah menghadirkan tantangan dan kesempatan bagi seluruh aspek kehidupan manusia, termasuk dalam dunia pendidikan. Pendidikan pada saat ini dihadapkan pada berbagai tantangan yang sangat kompleks, salah satu di antaranya adalah peningkatan Sumber Daya Manusia (SDM) yang mampu berlomba dan bergerak pada era globalisasi.

Teknologi Informasi dan Komunikasi (TIK) mengalami perkembangan yang sangat pesat dan secara fundamental telah membawa perubahan yang signifikan dalam percepatan dan inovasi dalam penyelenggaraan pendidikan di berbagai negara. Sejumlah negara juga telah mengintegrasikan Teknologi Informasi dan Komunikasi (TIK) dalam perencanaan dan penyelenggaraan pendidikan nasionalnya. Mereka bahkan telah mengubah budaya poembelajaran dengan mengintegrasikan teknologi digital ke dalam pembelajaran di sekolah.

Pendidikan dasar secara efektif dan efisien sangat diperlukan siswa pada masa ini. Apalagi jika pembelajaran tersebut berkaitan dengan pengenalan komputer sejak anakanak usia Sekolah Dasar yang sangat dianjurkan, sebab di era digital 4.0 semua informasi dapat diakses dengan mudah, demikian juga dengan siswa yang merupakan generasi penerus bangsa harus diajarkan komputer.

Salah satu tugas penting setiap pendidik adalah menyiapkan peserta didik mampu hidup di masa depan dengan baik. Dengan demikian, setiap guru perlu membekali dirinya dengan teknologi komputer sehingga dapat memperkenalkan dan mengajarkan komputer tersebut kepada anak didiknya.

Sejumlah negara juga telah mengintegrasikan Teknologi Informasi dan Komunikasi (TIK) dalam perencanaan dan penyelenggaraan pendidikan nasionalnya. Mereka bahkan telah mengubah budaya pembelajaran di sekolah menjadi tekonologi digital. Mulai Pendidikan Anak Usia Dini (PAUD), pendidikan dasar sampai pendidikan menengah para guru dituntut harus memiliki kompetensi pedagogik dan kompetensi profesi. Maka, untuk menunjang hal tersebut setiap guru harus didukung oleh penguasaan terknologi terbaru terutama teknologi internet.

Salah satu pemanfaatan ICT di sekolah adalah keterampilan menulis blog di internet. Hal ini sebagaimana yang diungkapkan oleh Tarigan (2008: 1) bahwa terdapat 4 (empat) keterampilan berbahasa yang tidak bisa dipisahkan yaitu keterampilan menyimak, keterampilan berbicara, keterampilan membaca, dan keterampilan menulis. Dari keempat keterampilan berbahasa tersebut, di mana menulis yang merupakan salah satu bentuk keterampilan berbahasa yang memiliki manfaat dan peran paling besar bagi kehidupan manusia, di samping keterampilan berbahasa yang lain. Sebab, dengan menulis seseorang dapat menuangkan segala ide, perasaan, dan gagasan yang dimilikinya ke dalam sebuah tulisan agar dapat dibaca dan dipahami oleh khalayak umum. Manusia yang memiliki keterampilan menulis yang baik berarti berpotensi untuk memiliki pengaruh yang kuat di masa depannya. 
Slamet (2008: 96 ) mengemukakan menulis sebagai kegiatan bagaimana menggali pikiran dan perasaan mengenai suatu subjek, memilih hal-hal yang akan ditulis, dan menentukan cara menuliskannya sehingga para pembaca dapat memahami tulisan tersebut dengan mudah dan jelas. Intinya menulis sebagai salah satu bentuk keterampilan berbahasa ragam tulis yang bersifat eskpresif atau produktif. Menulis dapat dikatakan keterampilan berbahasa yang rumit. Oleh sebab itu, seorang penulis yang terampil dalam tulisan-tulisannya memerlukan keseriusan dan keuletan yang tinggi agar tulisan tersebut bernilai lebih dan dapat diterima di masyarakat.

Istilah blog terdiri dari dua kata, yakni web dan log, sehingga sebuah blog yang ditulis seseorang dapat diartikan sebagai catatan harian kemudian disebarkan ke dalam website pribadi. Hal pertama untuk memulai menulis sebuah blog adalah menetapkan tujuan untuk apa blog itu dibuat. Apa yang ingin ditulis dan dipublikasikan. Hal seperti ini perlu dipertimbangkan masak-masak sebelum menentukan nama domain blog, yang tentunya mencerminkan isi blog. Tahap berikutnya adalah menentukan domain dan hosting untuk blog yang dibuat. Seorang blogger meskipun tidak memiliki latar belakang dan skill webmaster dapat membuat sendiri blognya mulai dari pembelian domain, menyewa hosting, desain web dan database, melakukan pengodean, hingga dapat mengenalkan web tersebut sebagaimana seorang webmaster bekerja.

Berdasarkan data di lapangan khususnya pada guru-guru Sekolah Dasar (SD) kebiasaan menulis kurang diminati. Hal ini disebabkan oleh ketiadaan waktu guru-guru Sekolah Dasar (SD) untuk menulis. Selain itu, tidak adanya atau kurangnya keterampilan tenaga pendidik atau guru untuk menulis. Cara agar dapat mengatasi kurangnya keterampilan guru dalam menulis adalah dengan memanfaatkan teknologi internet. Berkat bantuan media internet berbasis blog, diharapkan para pendidik dapat meningkatkan keterampilannya dalam menulis, khususnya pada saat mereka menulis silabus yang dituangkan ke dalam bentuk-bentuk perencanaan semester, mingguan, dan harian. Selain itu, dengan menulis di blog diharapkan pula guru-guru di Sekolah Dasar (SD) agar menuliskan kegiatan belajar mengajarnya. Selain itu, dapat mengajarkan ilmu yang telah dikuasainya kepada peserta didik atau siswa.

Tujuan dari dilaksanakannya kegiatan tersebut adalah 1) memberikan sosialisasi kepada para guru di SD Negeri Cipayung 04 Pagi Jakarta Timur mengenai pemahaman berkenaan dengan konsep-konsep, jenis-jenis, dan bentuk-bentuk literasi sehingga akan sangat membantu para guru dalam Kegiatan Belajar Mengajar (KBM) dan meningkatkan prestasi akademik peserta didik; 2) memberikan pemahaman dan pelatihan berkenaan tentang proses penggunaan email, memiliki, membuat, menggunakan atau memanfaatkan blog pribadi sebagai media pembelajaran.

Minimnya kesadaran guru-guru terutama dalam mengenalkan budaya literasi dan keterampilan menulis blog di internet kepada anak didiknya menjadi perhatian yang besar dalam kegiatan abdimas dan kegiatan tersebut penting dilaksanakan. Untuk itu, rencana pemecah masalah yang ditawarkan dari kegiatan pengabdian masyarakat ini adalah :

1. Mengenalkan konsep-konsep, jenis-jenis dan bentuk-bentuk literasi kepada para pendidik di Sekolah Dasar Negeri (SDN) Cipayung 04 Pagi Jakarta Timur agar dapat diterapkan kepada anak-anak didik atau siswa-siswanya.

2. Memberikan penjelasan kepada guru-guru di Sekolah Dasar, khususnya di Sekolah Dasar Negeri (SDN) Cipayung 04 Pagi Jakarta Timur mengenai proses penggunaan email, memiliki, membuat, menggunakan atau memanfaatkan blog pribadi sebagai media pembelajaran sehingga para guru di Sekolah Dasar Negeri Cipayung 04 Pagi Jakarta Timur tersebut diharapkan dapat memiliki keterampilan dalam kegiatan 
menulis secara produktif. Selain itu, keterampilan menulis yang dimiliki guru-guru Sekolah Dasar (SD) ini juga diharapkan dapat menunjang kreativitas peserta didiknya.

\section{METODE PELAKSANAAN}

Pengabdian masyarakat ini akan diselenggarakan pada para guru di Sekolah Dasar Negeri Cipayung 04 Pagi Jakarta Timur. Cara pemilihan mitra berdasarkan hasil observasi di Sekolah Dasar Negeri tersebut. Guru-guru di Sekolah Dasar Negeri Cipayung 04 Pagi Jakarta Timur tersebut sebagian besar belum mengetahui dan mendapatkan pemahaman berkenaan dengan konsep-konsep, jenis-jenis, dan bentukbentuk literasi dan belum memiliki akun email (gmail) serta masih belum memahami sepenuhnya tentang proses penggunaan email. Para guru juga tidak mampu memiliki, membuat, menggunakan atau memanfaatkan blog pribadi sebagai media pembelajaran sehingga para guru di Sekolah Dasar Negeri Cipayung 04 Pagi Jakarta Timur tersebut belum memiliki keterampilan dalam kegiatan menulis secara produktif.

Metode yang digunakan dalam kegiatan abdimas ini adalah metode ceramah, diskusi, tanya-jawab, dan pemodelan. Dengan penggunaan metode ini diharapkan Pengabdian Kepada Masyarakat ini dapat berjalan dengan efektif dan efisien. Kegiatan pengabdian masyarakat ini rencananya akan dilaksanakan pada 25 Maret sampai dengan 31 Agustus 2019. Mengenai waktu, akan disesuaikan dengan jadwal yang diizinkan oleh pihak penyedia tempat yaitu pihak mitra.

Alat-alat yang digunakan dalam pelatihan ini kerjasama antara tim abdimas dan mitra. Mitra menyediakan ruangan dan pengeras suara, sedangkan tim abdimas menyiapkan laptop, $L C D$ atau in focus, serta alat tulis dan buku sebagai pendukung untuk peserta abdimas.

\section{Tahapan Pelaksanaan Program}

1. Persiapan

Kegiatan-kegiatan persiapan yang dilakukan oleh tim, yaitu: Survei dan wawancara awal tempat pelaksanaan; Perizinan; Penentuan peserta; Pembuatan proposal dan penyelesaian administrasi perjanjian dengan mitra pengabdian masyarakat; Menyiapkan materi yang berkaitan dengan literasi dan keterampilan menulis blog di internet.

2. Pelaksanaan

Kegiatan pengabdian ini akan dilaksanakan setelah terjadi kesepakatan waktu dengan pihak mitra. Kegiatan ini akan dibuat menjadi beberapa pertemuan sehingga para guru di Sekolah Dasar Negeri Cipayung 04 Pagi Jakarta Timur lebih mengenal dan memahami tentang pentingnya literasi dan keterampilan menulis blog di internet sehingga akan sangat membantu para guru dalam kegiatan proses belajar mengajar dan meningkatkan prestasi akademik anak-anak didiknya.

3. Evaluasi

Evaluasi dilakukan dengan tujuan melihat kembali kegiatan yang telah dilakukan dan mengevaluasi segala kekurangan yang terjadi sehingga diharapkan terjadi peningkatan dalam pertemuan selanjutnya. 


\section{Pelaporan}

Laporan dibuat sebagai bentuk pertanggungjawaban tim terhadap kegiatan yang dilaksanakan. Tahapannya yaitu pelaporan awal, perevisian laporan, dan pelaporan akhir.

\section{HASIL DAN PEMBAHASAN}

Hasil yang dicapai dalam kegiatan pelaksanaan pengabdian kepada masyarakat yang berjudul "Literasi dan Pembuatan Blog Pada Guru SDN Cipayung 04 Pagi", adalah sebagai berikut :

1. Guru-guru di Sekolah Dasar tersebut telah mendapatkan pengetahuan dan pengalaman berkenaan dengan konsep-konsep, jenis-jenis, dan bentuk-bentuk literasi sehingga akan sangat membantu para guru dalam kegiatan proses belajar mengajar dan meningkatkan prestasi akademik anak-anak didiknya.

2. Guru-guru di Sekolah Dasar tersebut telah mendapatkan pemahaman berkenaan tentang proses penggunaan email, memiliki, membuat, menggunakan atau memanfaatkan blog pribadi sebagai media pembelajaran sehingga para guru di sekolah tersebut diharapkan dapat memiliki keterampilan dalam kegiatan menulis secara produktif yang dapat menunjang kreativitas peserta didiknya. Beberapa foto blog Sekolah Dasar Negeri Cipayung 04 Pagi Jakarta Timur.

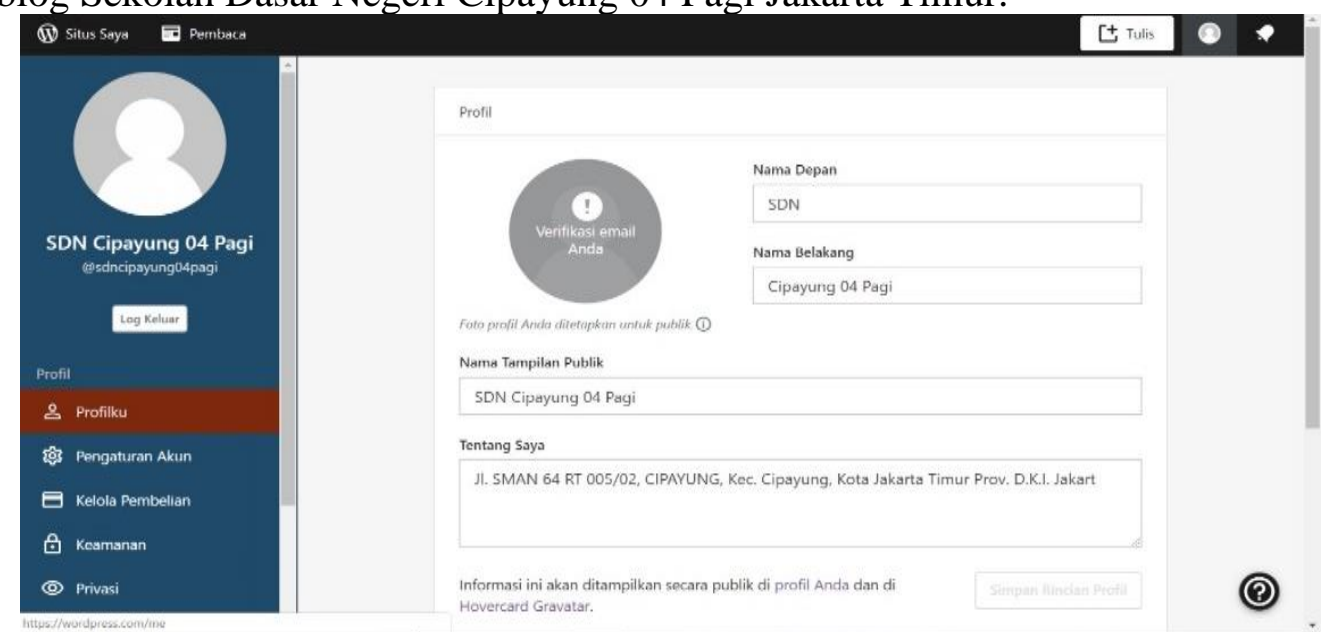

Gambar 1. Hasil Blog Guru SDN Cipayung 04 Pagi

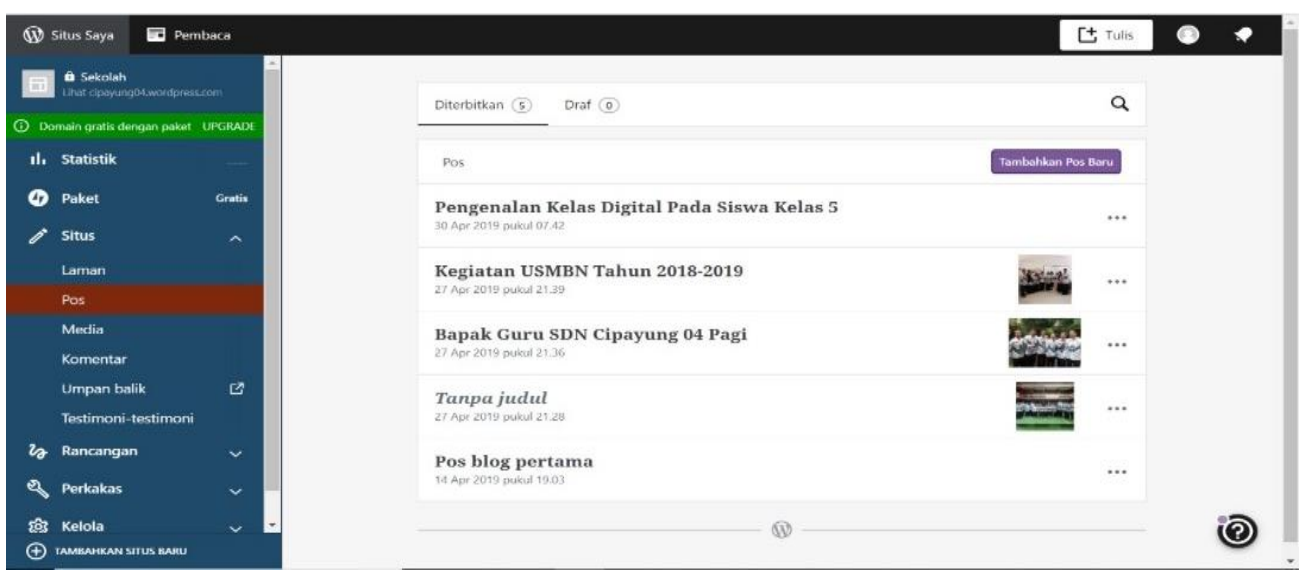

Gambar 2. Tampilan Blog Guru SDN Cipayung 04 Pagi 
3. Kegiatan abdimas yang dilakukan tim Unindra kepada guru-guru di Sekolah Dasar Negeri Cipayung 04 Pagi Jakarta Timur mendapatkan antusias yang tinggi dari para guru tersebut. Adapun pertanyaan-pertanyaan yang disampaikan oleh peserta abdimas kepada tim. Adapun pertanyaan-pertanyaan yang diajukan adalah sebagai berikut :

a. Kalau kita mau memajang foto kegiatan sekolah bagaimana caranya?

Jawab:

Jika bapak dan ibu sudah memiliki akun email dan membuat blog di wordpress.com, bapak dan ibu dapat memajang/memosting foto-foto kegiatan sekolah dengan menggunakan atau memanfaatkan dashboard yang telah disediakan dalam blog tersebut, sebab dashboard adalah halaman untuk melakukan editing terhadap blog yang telah dibuat, baik itu file dokumen, foto, maupun video. Wordpress juga menyediakan fasilitas untuk mengupload fotofoto kegiatan sekolah bapak dan ibu guru dengan memberikan link-link khusus pada dokumen atau foto yang telah diupload tersebut. Bapak dan ibu guru juga dapat mengklik media, yang merupakan tempat kumpulnya foto-foto, video dan audio. Bapak dan ibu tinggal pilih media apa yang akan digunakan untuk dipublikasikan.

b. Berarti kalau kita kita mau membuat blog, kita harus memiliki email dulu ya?

Jawab:

Ya benar, sebab memiliki email merupakan hal yang wajib bagi seseorang yang ingin membuat blog. Selain itu, semua media sosial yang kita gunakan pasti akan dimintai untuk memasukkan alamat email bapak dan ibu guru.

c. Kalau membuat blog berarti terkait dengan literasi apa?

Jawab:

Literasi digital, sebab literasi digital merupakan kemampuan dalam pengenalan dasar-dasar komputer, pemanfaatan internet, serta program-program yang berkaitan dengan media digital.

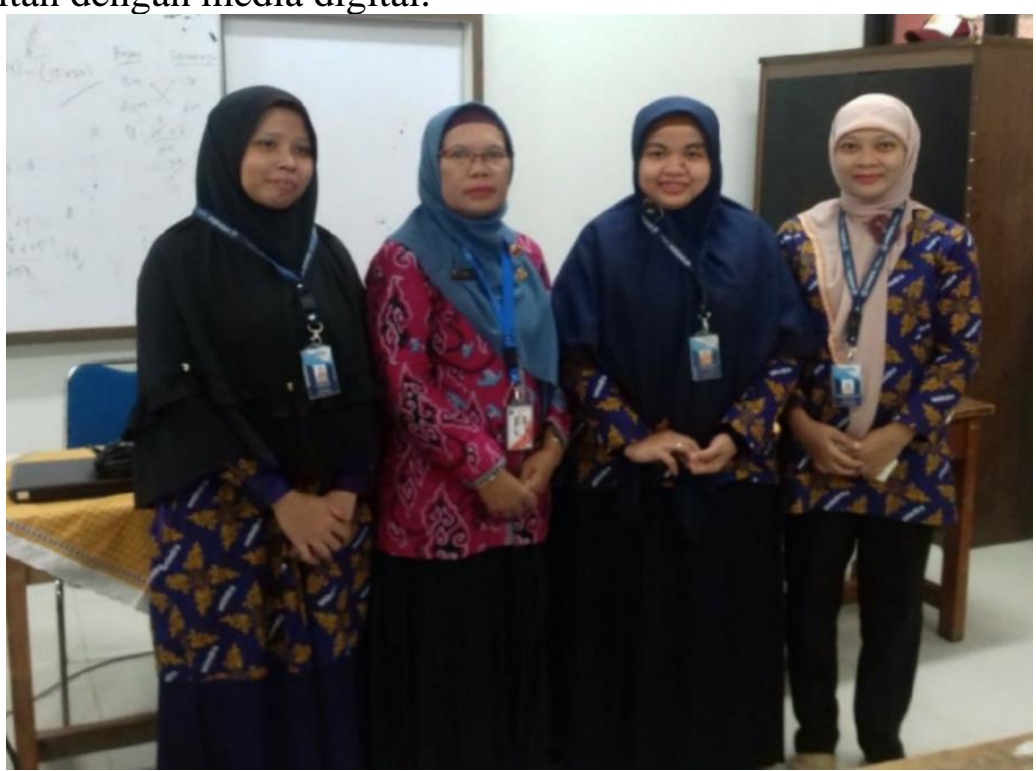

Gambar 3. Tim Abdimas beserta Kepala SDN Cipayung 04 Pagi 


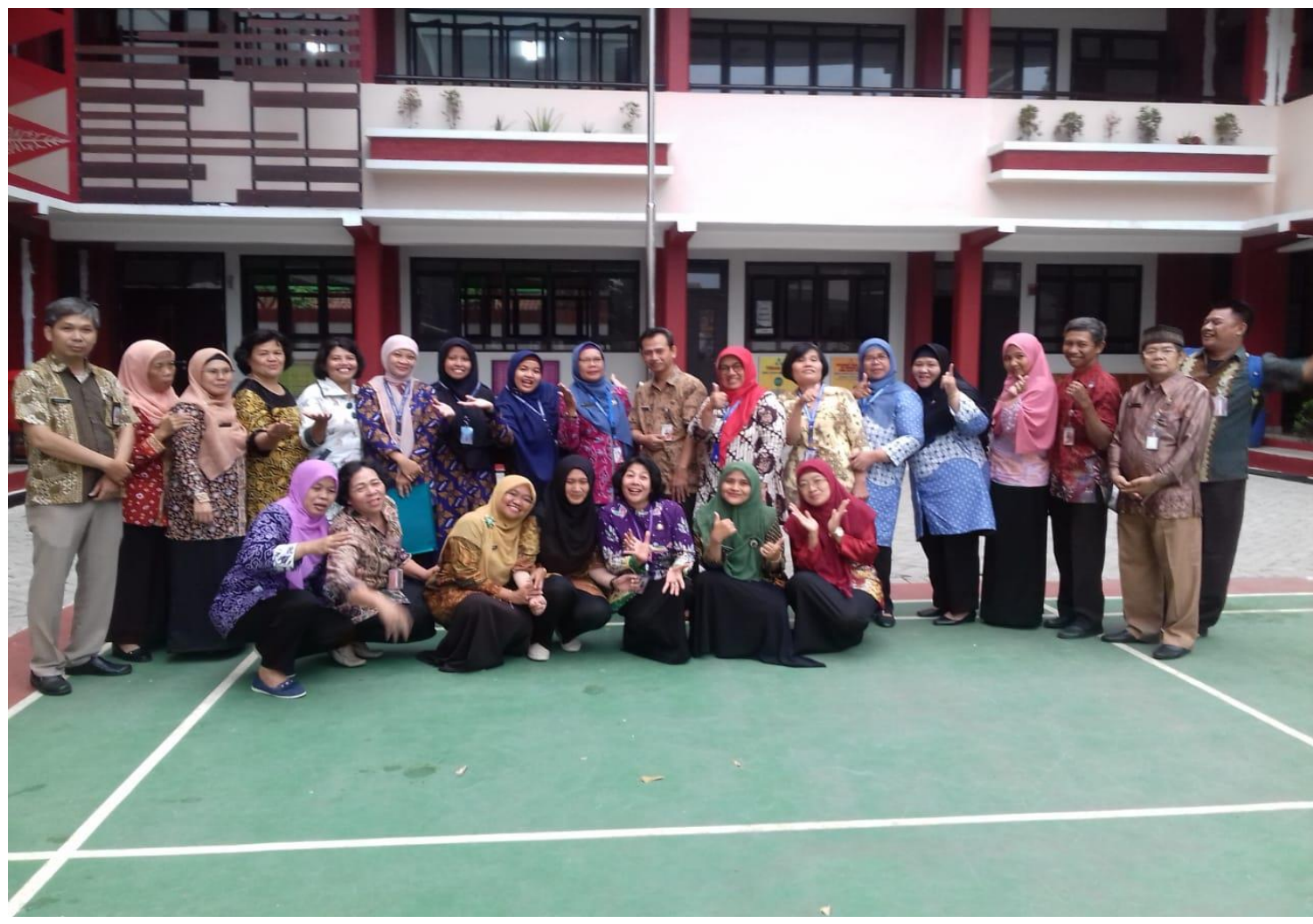

Gambar 4. Tim Abdimas beserta Para Guru SDN Cipayung 04 Pagi

\section{SIMPULAN}

Simpulan yang dapat dipetik dalam kegiatan pengabdian kepada masyarakat (Abdimas) ini adalah sebagai berikut :

1. Literasi tidak hanya terkait dengan baca dan tulis. Namun, literasi juga mencakup hal yang cukup luas, sebab di dalamnya terdapat pengertian tentang bagaimana seseorang mempunyai kecakapan dalam praktik dan berkomunikasi dalam masyarakat yang terkait dengan pengetahuan, bahasa, budaya, dan sebagainya.

2. Pemanfaatan media blog di Sekolah-sekolah Dasar perlu dilakukan, sebab dengan memanfaatkan blog, para guru dapat mengasah kemampuan dan keterampilan menulis. Selain itu, dengan memanfaatkan blog di sekolah, para guru secara tidak langsung memperkenalkan sekolah mereka kepada publik, sehingga secara otomatis masyarakat luas dapat mengetahui kegiatan-kegiatan dan prestasi-prestasi yang telah dicapai di Sekolah Dasar tersebut.

\section{UCAPAN TERIMA KASIH}

Syukur Alhamdulillah, tim Pengabdian Kepada Masyarakat lafadzkan kepada Allah SWT atas segala rahmat, taufiq, dan hidayah-Nya, sehingga kegiatan Pengabdian Kepada Masyarakat ini dapat terlaksana dengan baik. Salawat dan salam semoga tercurah kepada Nabi dan Rasul junjungan Muhammad SAW beserta keluarga, sahabat, dan segenap umatnya hingga akhir zaman. 
Keberhasilan kegiatan Pengabdian Kepada Masyarakat ini tidak terlepas dari bantuan dana Pengabdian Kepada Masyarakat Unindra semester genap tahun 2019 yang diberikan kepada tim. Oleh karena itu, dengan segala hormat dan ketulusan hati tim mengucapkan terima kasih yang sebesar-besarnya kepada : Drs. Hartadi, selaku Warek II Unindra, Drs. H. Achmad Sjamsuri, M.M., selaku Kepala Lembaga Penelitian dan Pengabdian Masyarakat, Munzir, M.M., M.Pd., selaku Kepala Pusat Pengabdian Kepada Masyarakat Unindra.

Tim Pengabdian Kepada Masyarakat Unindra juga mengucapkan terima kasih kepada Entin Rosita, S.Pd., M.M., selaku Kepala Sekolah Dasar Negeri Cipayung 04 Pagi Jakarta Timur, serta para guru di Sekolah Dasar Negeri tersebut yang telah memberikan kesempatan kepada tim untuk melaksanakan kegiatan Pengabdian Kepada Masyarakat.

\section{DAFTAR PUSTAKA}

Heryati, Y., dkk. (2010). Model Inovatif Pembelajaran Bahasa Indonesia. Jakarta: Multi Kreasi Satudelapan.

Ihsan, F. (2005). Dasar-dasar Kependidikan. Jakarta : Rineka Cipta.

Koesoema A, D. (2007). Pendidikan Karakter: Strategi Mendidik Anak di Zaman Modern. Jakarta: Grasindo.

Slamet. (2008). Dasar-Dasar Keterampilan Berbahasa Indonesia. Lembaga Pengembangan Pendidikan UNS dan UPT Penerbit dan Percetakan UNS (unspress).

Tarigan, H. G. (2008). Menulis: Sebagai Suatu Ketrampilan Berbahasa. Bandung: Angkasa.

Tim Pengembang Pusat Kurikulum. (2007). Standar Perkembangan Dasar Pendidikan Anak Usia Dini. Jakarta: Depdiknas.

Undang-Undang No. 20 Tahun 2003 tentang Sistem Pendidika Nasional 